\title{
MECHANISM OF INHIBITION OF PEPSIN BY PEPSTATIN. II
}

\author{
Setsuko Kunimoto, TakaAki Aoyagi, Rinzo Nishizawa, \\ TOMOYoshi Komai,* TOMIO TAKeUCHI \\ and Hamao Umezawa \\ Institute of Microbial Chemistry, \\ Kamiosaki 3-14-23, Shinagawa-ku, Tokyo, Japan \\ *National Institute of Health, \\ Shinagawa-ku, Tokyo, Japan
}

(Received for publication February 28, 1974)

\begin{abstract}
Pepstatin, a strongly bound inhibitor of acid proteases, does not instantaneously bind to pepsin. The dissociation constant of pepsin-pepstatin complex is $9.7 \times 10^{-11} \mathrm{M}$ using Phe.Gly.His.Phe $\left(\mathrm{NO}_{2}\right) \cdot \mathrm{Phe} \cdot \mathrm{Ala} \cdot \mathrm{PheOMe}$ as substrate. Difference ultraviolet absorption spectra show conformational change of pepsin in interaction with pepstatin. The binding of pepsin with pepstatin is stoicheometric and the normality of pepsin can be easily titrated by pepstain. Pepsin modified by 1,2-epoxy-3-( $p$-nitrophenoxy) propane, 2,3-butanedione, $\alpha$-diazo- $p$-bromoacetophenone or $p$-bromophenacyl bromide shows reduced pepstatin-binding activity.
\end{abstract}

Pepstatin produced by a Streptomyces ${ }^{1)}$ is a specific inhibitor of various acid proteases ${ }^{2,3)}$ and renin $^{3)}$. In a previous paper $^{4)}$, we reported the strong binding of pepstatin with pepsin. In this paper, the dissociation constant of pepsin-pepstatin complex and the binding of pepstatin with the active site of pepsin are described.

\section{Materials and Methods}

Enzyme and inhibitors: Pepsin (twice crystallized, lot 28B-1900) was purchased from Sigma Chemical Co., U.S. A. Pepsinogen $(2,750 \mathrm{u} / \mathrm{mg})$ and bovine trypsin (twice crystallized) were purchased from Worthington Biochemical Co., U.S. A. Bovine serum albumin (Fraction V) was purchased from Armour Laboratories, U.S. A. Pepstatin was prepared as described in a previous paper $^{1)}$. Radioactive pepstatin (specific activity was $2.2 \times 10^{5} \mathrm{dpm} / \mu \mathrm{g}$ ) was prepared by the exposure to tritium gas followed by purification. All the other reagents employed were analytical grade.

Synthesis of Phe-Gly-His-Phe $\left(\mathrm{NO}_{2}\right)$-Phe-Ala-PheOMe: All amino acids used had the Lconfiguration. The synthesis of the protected heptapeptide-resin was carried out according to the usual solid phase procedure $\left.{ }^{5,8}\right)$ starting from Boc-Phe-resin $(10 \mathrm{~g} ; 0.53 \mathrm{~m}$ mole of Phe $/ \mathrm{g}$, Boc; tert-butyloxycarbonyl). The coupling steps were carried out with 3 -fold excess of dicyclohexylcarbodiimide and Boc-amino acids except $\mathrm{Phe}\left(\mathrm{NO}_{2}\right)$ which was protected with Aoc group (Aoc; tert-amyloxycarbonyl). Boc and Aoc groups were removed with $1 \mathrm{~N} \mathrm{HCl}$ in acetic acid for 30 minutes. The imidazole ring of histidine was protected with the tosyl group. $p$-Nitrophenylalanine prepared by the method of BERGEL and STOCK $^{7)}$ was reacted with $t$-amyl azidoformate in the usual method ${ }^{8)}$ to give Aoc-Phe $\left(\mathrm{NO}_{2}\right)$ in $70.7 \%$ yield as the dicyclohexylamine salt, m.p. $168 \sim 170^{\circ} \mathrm{C},[\alpha]_{\mathrm{D}}^{20}+51.6^{\circ}$ (c 0.5, ethanol). Anal. Calcd. for $\mathrm{C}_{27} \mathrm{H}_{43} \mathrm{O}_{6} \mathrm{~N}_{3}: \mathrm{C} 64.13, \mathrm{H}$ 8.57, N 8.31. Found: $\mathrm{C} 64.31, \mathrm{H} \mathrm{8.74,} \mathrm{N} \mathrm{7.96.} \mathrm{After} \mathrm{the} \mathrm{last} \mathrm{coupling,} \mathrm{the} \mathrm{weight} \mathrm{of} \mathrm{the} \mathrm{pro-}$ tected peptide-resin was $13.8 \mathrm{~g}$. A portion of the peptide-resin $(12.4 \mathrm{~g})$ was suspended in $1 \mathrm{~N}$ triethylamine methanolic solution $(500 \mathrm{ml})$. White precipitate appeared after one day, and then dimethylformamide $(100 \mathrm{ml})$ was added, and the suspension was stirred for one more day. The 
suspension was filtered and washed with dimethylformamide $(50 \mathrm{ml})$. The combined solution was poured into cold water $(2,500 \mathrm{ml})$. The precipitate was collected and washed with cold water and ether. The protected peptide ester was recrystallized from dimethylformamide and water. The yield of the protected peptide ester was $4.1 \mathrm{~g}$. The protective groups were removed by stirring for 60 minutes at $0^{\circ} \mathrm{C}$ in anhydrous $\mathrm{HF}$ containing anisole. After removal of HF and anisole under reduced pressure, Dowex $1\left(\mathrm{OH}^{-}\right)$was added to the solution of the peptide in aqueous methanol for neutralization of HF salt. The resin was filtered and washed with dimethylformamide. The combined solution was concentrated under reduced pressure and the crude peptide ester was obtained by addition of methanol. It was recrystallized from methanol and dimethylformamide. The peptide ester was obtained as $0.52 \mathrm{~g}$ of crystals m.p. $223^{\circ} \mathrm{C}$ (dec.), $[\alpha]_{D}^{29}-33.9^{\circ}$ (c 0.5, dimethylformamide). Anal. Calcd. for $\mathrm{C}_{48} \mathrm{H}_{54} \mathrm{~N}_{10} \mathrm{O}_{10}: \mathrm{C} 61.92, \mathrm{H} 5.85$, $\mathrm{N}$ 15.05. Found: C 61.74, H 5.78, N 14.90. On thin-layer chromatography using Silica Gel G (E. Merck), the peptide ester gave a single spot at $\mathrm{Rf} 0.64$ with butanol-acetic acid-water (4:1:1) and Rf 0.74 with butanol-acetic acid - water-pyridine (15:3:12:10).

The assay of pepsin activity: The hydrolysis of hemoglobin and acetyl-L-phenylalanyl-Ldiiodotyrosine (APDT) by pepsin was measured spectrophotometrically in the manner described previously ${ }^{2,4}$. The enzyme reaction was started by addition of substrate except as otherwise noted. The rate of peptic hydrolysis of Phe-Gly.His.Phe $\left(\mathrm{NO}_{2}\right) \cdot \mathrm{Phe} \cdot \mathrm{Ala} \cdot \mathrm{PheOMe}$ was determined at $37^{\circ} \mathrm{C}$ by continuous measuring of the increase of absorbance at $310 \mathrm{~nm}$ with a Gilford recording spectrophotometer, model 2400. The substrate was dissolved at $100 \mathrm{~mm}$ in formic acid and diluted to the desired concentration with $0.04 \mathrm{~m}$ formate buffer at $\mathrm{pH} 4.0$.

Difference spectral measurements: Difference spectral measurements were carried out with a Hitachi EPS-3T recording spectrophotometer using matched tandem double cells with 0.45 $\mathrm{cm}$ light path length for each compartment. For difference absorbance measurements at 288 $\mathrm{nm}$, a Gilford recording spectrophotometer was used at expanded scale.

Preparation of chemically medified pepsins: Two aspartic acid residues in the pepsin-active site were modified by esterification with $p$-bromophenacyl bromide or/and $\alpha$-diazo- $p$-bromoacetophenone as described by ERLANGer et al. ${ }^{9)}$ Esterification of the $\beta$-carboxyl group of aspartic acid by diazoacetylnorleucine methyl ester (DAN) and 1,2-epoxy-3-( $p$-nitrophenoxy) propane (EPNP) was performed as described by RAJAGOPALAN et al. ${ }^{10)}$ and $\mathrm{TANG}^{11}$, respectively. Four kinds of acetylated pepsins were prepared as described by Hollands and FRUTON ${ }^{12)}$ with acetylimidazole, the concentration of which was 1.4, 5.6, 8.4 and $25.2 \mathrm{~mm}$. Arginine located on 12th residue from the carboxy terminus was modified with biacetyl (2,3-butanedione) by the method of HUANG and TANG ${ }^{13)}$.

Determination of binding of pepstatin to modified pepsins: The binding of ${ }^{3} \mathrm{H}$-pepstatin to modified pepsins was examined by gel filtration with the column method previously described $^{4)}$ and with a batchwise dialysis method. Batchwise dialysis was carried out as described by FASElla et al. ${ }^{14)}$ : $\quad 300 \pm 3 \mathrm{mg}$ of Sephadex G-25 (fine) was placed in each test tube with $1.5 \mathrm{ml}$ of $0.2 \mathrm{M}$ sodium acetate buffer at $\mathrm{pH} 5.6$ and the gel was allowed to swell overnight; each modified pepsin and ${ }^{3} \mathrm{H}$-pepstatin were dissolved in the same buffer to concentrations of 3.6 $\mathrm{mg} / \mathrm{ml}$ and $100 \mu \mathrm{g} / \mathrm{ml}$, respectively; after standing for at least 5 minutes at room temperature $0.05 \mathrm{ml}$ of this solution was added to the gel and the test tube was shaken vigorously for one minute; the slurry was filtered under weak pressure through a glass filter to get $0.5 \mathrm{ml}$ of filtrate; the radioactivity of the filtrate was determined in a Beckman Liquid Scintillation System with BrAY's scintillation solution ${ }^{15)}$. The volume outside the gel was determined spectrophotometrically with blue dextran 2000. The dissociation constant of pepstatin-enzyme complex could be calculated from the concentrations of ${ }^{3} \mathrm{H}$-pepstatin inside and outside the gel. Under the experimental conditions, absorption of ${ }^{3} \mathrm{H}$-pepstatin to Sephadex gel could not be neglected and the added amount of ${ }^{3} \mathrm{H}$-pepstatin was corrected for maximum binding of ${ }^{3} \mathrm{H}$-pepstatin to gel $(7 \%)$. 


\section{Results and Discussion}

Effect of the Order of Addition of Reaction Components on Inhibition

\section{of Pepsin by Pepstatin}

In the absence of pepstatin, the substrate, Phe.Gly.His.Phe $\left(\mathrm{NO}_{2}\right) \cdot \mathrm{Phe} \cdot \mathrm{Ala} \cdot \mathrm{PheOMe}$ was completely hydrolyzed within 10 minutes as shown in Fig. 1. When pepsin was added to a mixture of substrate and various concentrations of pepstatin, the hydrolysis proceeded slowly for sometime and stopped in spite of the presence of most of substrate. If pepsin and pepstatin were allowed to react first, the hydrolysis reaction did not occur. This result can be

Fig. 1. Effect of the order of mixing on the inhibition of pepsin by pepstatin.

Incubation mixture was $3 \mathrm{ml} 0.04 \mathrm{M}$ formate buffer, $\mathrm{pH} 4.0$ containing $0.1 \mathrm{~mm}$ Phe.Gly.His. Phe $\left(\mathrm{NO}_{2}\right) \cdot$ Phe Ala. Phe OMe $1.73 \times 10^{-8} \mathrm{~N}$ pepsin and various concentrations of pepstatin. The concentrations of pepstatin were (a) none, (b) $2.43 \times 10^{-8} \mathrm{M}$, (c) $4.86 \times 10^{-8} \mathrm{M}$, (d) $7.29 \times 10^{-8} \mathrm{M}$ and (e) $2.43 \times 10^{-8} \mathrm{M}$. In the case of (a) (d) the enzyme was added last. In the case of (e) the substrate was added last.

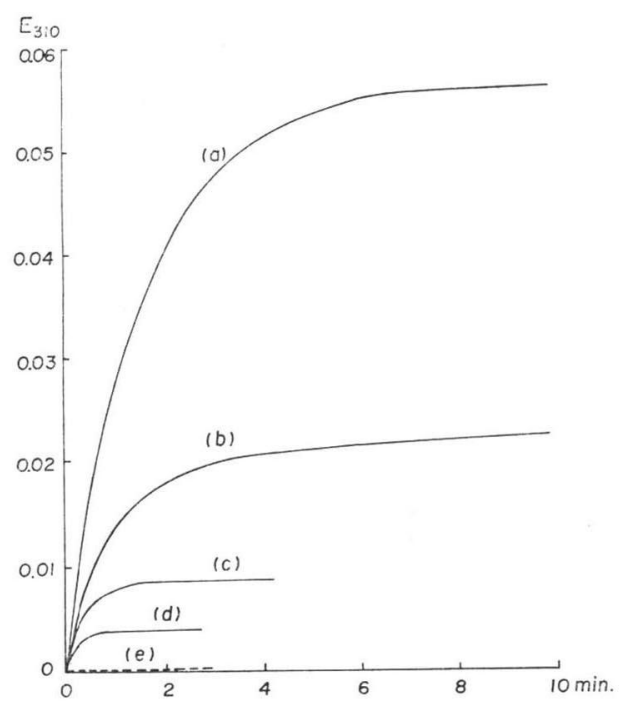
understood if the binding reaction between pepsin and pepstatin proceeds slowly. As shown in Fig. 1, this binding reaction is completed more rapidly as the pepstatin concentration is increased. A similar effect of order

Fig. 2. Effect of the order of mixing on the inhibition of peptic hydrolysis of hemoglobin by pepstatin.

Incubation mixture $(2 \mathrm{ml})$ contained $0.8 \mu \mathrm{g}$ of pepsin, $0.25 \%$ hemoglobin and various amounts of pepstatin. It was incubated at $37^{\circ} \mathrm{C}$ for 25 minutes. In (a) the substrate was added last. In (b) pepsin was added last.

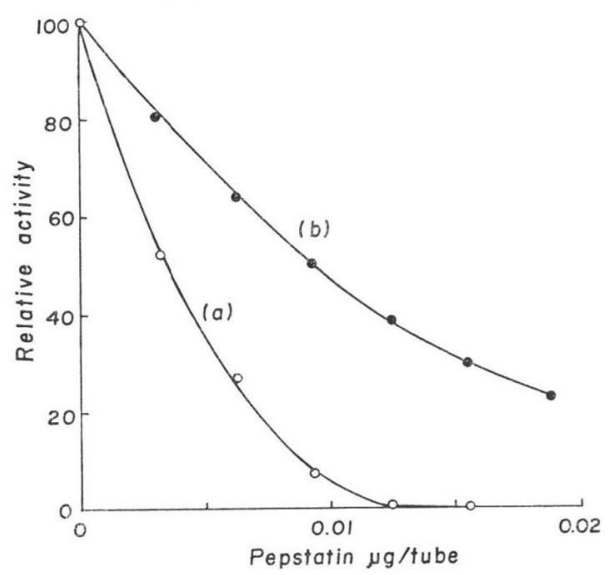

Fig. 3. Effect of pepstatin concentration on the hydrolysis of Phe.Gly. His. Phe $\left(\mathrm{NO}_{2}\right) \cdot$ Phe $\cdot$ Ala. PheOMe by pepsin.

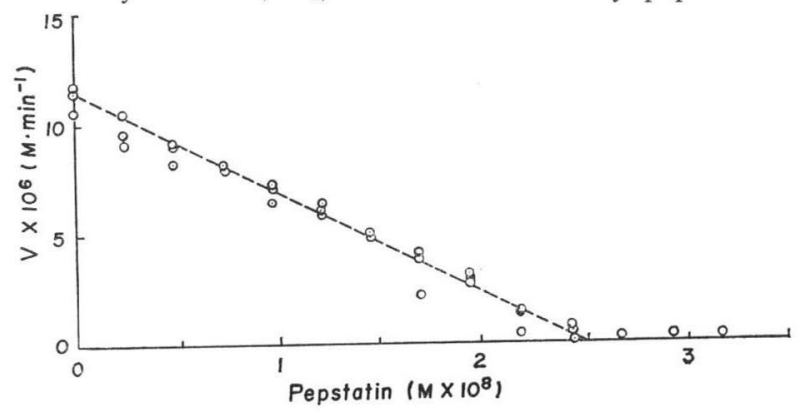


of addition of reactants was obtained in hydrolysis of hemoglobin. Inhibition curve is shown in Fig. 2. If pepsin was added to a mixture of pepstatin and hemoglobin, it was found that the observed inhibition was much lower than that in the usual inhibitor assay system where pepstatin and pepsin were preincubated for 3 minutes at $37^{\circ} \mathrm{C}$ before the addition of hemoglobin.

\section{Estimation of Dissociation Constant of Pepsin-Pepstatin Complex}

$\mathrm{Phe} \cdot \mathrm{Gly} \cdot \mathrm{His} \cdot \mathrm{Phe}\left(\mathrm{NO}_{2}\right) \cdot \mathrm{Phe} \cdot \mathrm{Ala} \cdot \mathrm{PheOMe}$ is considered the most suitable synthetic peptide for kinetic study on pepsin ${ }^{16)}$, because $k_{\text {cat }}$ is very large and experiments can be seen at very low enzyme concentrations and a short reaction times. The inhibition curve of pepstatin for peptic hydrolysis with this substrate is shown in Fig. 3. The inhibitor concentration (I) at which the tangent to this curve at $I_{t}=0$ cut the abscissa will be given by the equation obtained by MORRISON ${ }^{17}, I=$ $E_{t}+\{K m+S /(K m / K i)\}$, if pepstatin is a compe-
Fig. 4. Difference ultraviolet spectrum of pepsinpepstatin complex vs. pepsin.

(a) Difference spectrum. Pepsin was dissolved at $1.2 \mathrm{mg} / \mathrm{ml}$ in $0.04 \mathrm{~m}$ formate buffer, $\mathrm{pH} 4.0$. Pepstatin concentrations were a) $6.66 \mu \mathrm{g} / \mathrm{ml}$, b) $13.3 \mu \mathrm{g} / \mathrm{ml}$, c) $20.0 \mu \mathrm{g} / \mathrm{ml}$ and d) $26.6 \mu \mathrm{g} / \mathrm{ml}$.

(b) The increase in absorptivity at $288 \mathrm{~nm}$ against added pepstatin. Pepstatin was added to $3 \mathrm{ml}$ of $1 \mathrm{mg} / \mathrm{ml}$ pepsin solution.
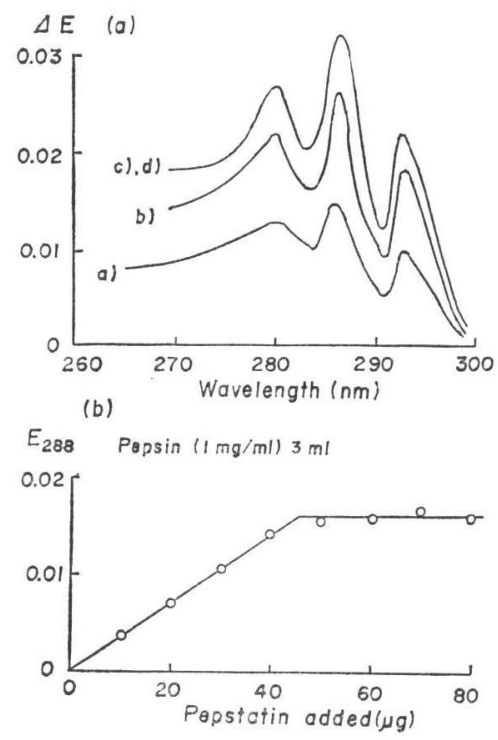

Table 1. Enzyme activity and pepstatin-binding activity of modified pepsins and pepsinogen

\begin{tabular}{|c|c|c|c|c|}
\hline \multirow{2}{*}{ Enzyme } & \multicolumn{2}{|c|}{ Enzyme activity } & \multicolumn{2}{|c|}{$\begin{array}{l}\text { Binding of pepstatin deter- } \\
\text { mined by gel filtration }\end{array}$} \\
\hline & Hemoglobin & APDT & $\begin{array}{l}\text { Column } \\
\text { method }\end{array}$ & ${ }_{(K i)}^{\text {Batch method }}$ \\
\hline Pepsin & 100 & 100 & 100 & M \\
\hline EPNP-pepsin & 16 & & 20 & $8.9 \times 10^{-6}$ \\
\hline Biacetyl-pepsin & 29 & & 43 & $3.0 \times 10^{-8}$ \\
\hline $\begin{array}{l}p \text {-Bromophenacyl bromide and } \alpha \text {-diazo-p- } \\
\text { bromoacetophenone-pepsin }\end{array}$ & 0.41 & & 10 & $2.1 \times 10^{-8}$ \\
\hline$\alpha$-Diazo-p-bromoacetophenone-pepsin & 0.74 & & 64 & $1.8 \times 10^{-8}$ \\
\hline p-Bromophenacyl bromide-pepsin & 25 & & 81 & $1.0 \times 10^{-8}$ \\
\hline Diazoacetylnorleucine methyl ester-pepsin & 2 & & & $5.8 \times 10^{-7}$ \\
\hline Acetylimidazole-pepsin & 103 & 196 & 101 & \\
\hline$"$ & 81 & 194 & 93 & \\
\hline " & 74 & 331 & 88 & \\
\hline " & 46 & 311 & 80 & \\
\hline Heat denatured pepsin & 0 & & & $1.0 \times 10^{-5}$ \\
\hline Pepsin (pH 7.5) & 0 & & & $4.6 \times 10^{-5}$ \\
\hline Pepsinogen ( $\mathrm{pH}$ 7.5) & 0 & & & $4.1 \times 10^{-5}$ \\
\hline
\end{tabular}


titive inhibitor. $E_{t}$, total pepsin concentration is $2.43 \times 10^{-8} \mathrm{~N}$ from the result of normality titration with pepstatin. Substrate concentration is $1.67 \times 10^{-4} \mathrm{M}$. $\mathrm{Km}$ of this substrate was $4 \times 10^{-5} \mathrm{M}$ from LineweAver-Burk plot. From these values $K i$ is calculated as $9.7 \times 10^{-11} \mathrm{M}$. This value is an approximate one, because the enzyme concentration is still too high to obtain the correct value. In our previous paper ${ }^{4)}$, the dissociation constant of pepsin-pepstatin complex was roughly estimated to be less than $3 \times 10^{-9} \mathrm{M}$ from the hydrolysis of N-acetyl-L-phenylalanylL-diiodotyrosine.

Conformational Change of Pepsin Structure Caused by Interaction with Pepstatin

As shown in Fig. 4a, the difference ultraviolet absorption spectra show an increase in absorption at 279, 287 and $293 \mathrm{~nm}$. The increase is linear and stoichiometric with pepstatin concentration as shown in Fig. 4b, as expected from pseudo-irreversible binding of pepsin and pepstatin. In a previous paper $^{4}$ ) we reported that pepstatin could be used for titrating pepsin normality by measuring pepsin activity in the presence of pepstatin. Normality titration of pepsin can be done more easily by the difference spectral technique as shown in Fig. 4b. In this case the ratio of normality/molarity was 0.78 , a value almost equal to the result of 0.76 obtained by the activity-measuring method. The difference spectra suggest that some conformational change in pepsin molecule might occur by the interaction with pepstatin. However, the optical rotatory dispersion spectrum in the far-ultraviolet region of pepsin was not altered by the addition of equimolar pepstatin. These results suggest that pepstatin does not change the peptide-chain conformation but brings about a fine structural change in the tyrosine and tryptophan environment as observed by difference spectra.

\section{Binding of Pepstatin to Chemically Modified Pepsins}

In order to clarify the binding site of pepstatin, various chemical modifications of pepsin were tested for binding with pepstatin. Three different $\beta$-carboxyls of aspartic acid residues were selectively modified by EPNP, diazoketones and $p$-bromophenacyl bromide. The arginine located at the 12 th residue from the carboxyl terminus was modified by biacetyl. These modifications lead to partial or complete inactivation of enzymatic activity. Some tyrosyl residues were acetylated by the treatment with various concentrations of acetylimidazole. This modification is known to reduce the proteinase activity of pepsin toward hemoglobin but to enhance the rate of cleavage of the small synthetic peptide ${ }^{16,18)}$. The binding of pepstatin to modified pepsins was examined by gel filtration with the column and the batchwise dialysis methods. The former shows the degree of dissociation of EI complex under the experimental conditions. From the latter method the dissociation constants $(K i)$ are calculated, but they are not accurate because of the absorption of pepstatin against Sephadex. In our experimental condition determined from the solubility of pepstatin $7 \%$ of added pepstatin absorbed on the gel. The results are summarized in Table 1. The two methods gave the same results except with the double modification of $p$-bromophenacyl bromide and $\alpha$-diazo- $p$-bromoacetophenone. The order of increasing binding weakening by modification was EPNP, biacetyl, $\alpha$-diazo-p-bromoacetophenone and $p$-bromophenacyl bromide. All the modification except DAN increased the dissociation constants of EI complex to the order of $10^{-6} \mathrm{M}$ from $10^{-10} \mathrm{M}$. Acetylation of tyrosyl residues caused a decrease of binding of pepstatin to the enzyme in proportion to the concentration of acetylimidazole. Pepsin denatured by heat treatment at $95^{\circ} \mathrm{C}$ for 5 minutes had pepstatin binding activity with a $K i=1.0 \times 10^{-5} \mathrm{M}$. Pepsin and pepsinogen were tested by batchwise gel fil- 
tration using $0.2 \mathrm{M}$ tris- $\mathrm{HCl}$ buffer, $\mathrm{pH} 7.5$ in which pepsin was irreversibly denatured. Denatured pepsin and pepsinogen had $K i$ of $4.6 \times 10^{-5} \mathrm{M}$ and $4.1 \times 10^{-5} \mathrm{M}$, respectively. To test for nonspecific binding of pepstatin to proteins bovine serum albumin and bovine trypsin were checked using $0.2 \mathrm{M}$ tris- $\mathrm{HCl}$ buffer, $\mathrm{pH} 7.5$. These $K i$ values were $2.8 \times 10^{-5} \mathrm{M}$ and $1.1 \times 10^{-4}$ M, respectively. Nonspecific binding of pepstatin with proteins by hydrophobic interaction is quite strong as shown by the $10^{-5} \mathrm{M}$ value for $\mathrm{Ki}$. Pepstatin-binding activity of denatured pepsin and pepsinogen was similar to nonspecific binding. These studies on chemically modified pepsins and denatured pepsin suggest that pepstatin binds to the active site of pepsin, and the pepstatin-binding site of pepsin is considerably flexible in conformation, similar to the report of SACHDEV et al. ${ }^{19)}$ Various modified amino acids are thought to be in the area interacting with pepstatin.

\section{References}

1) Umezawa, H.; T. Aoyagi, H. Morishita, M. Matsuzaki, M. Hamada \& T. Takeuchi: Pepstatin, a new pepsin inhibitor produced by actinomycets. J. Antibiotics 23: 259 262, 1970

2) Aoyagi, T.; S. Kunimoto, H. Morishima, T. Takeuchi \& H. Umezawa: Effect of pepstatin on acid proteases. J. Antibiotics 24: 687 694, 1971

3) Aoyagi, T.; H. Morishima, R. Nishizawa, S. Kunimoto, T. Takeuchi, H. Umezawa \& H. IKEZAWA: [Biological activity of pepstatins, pepstanone $\mathrm{A}$ and partial peptides on pepsin, cathepsin D and renin. J. Antibiotics 25: 689 694, 1972

4) Kunimoto, S.; T. Aoyagi, H. Morishima, T. Takeuchi \& H. Umezawa: Mechanism of inhibition of pepsin by pepstatin. J. Antibiotics 25: 251 255, 1972

5) Merrifield, R.B.: Solid phase peptide synthesis. I. The synthesis of a tetrapeptide. J. Am. Chem. Soc. 85: 2149 2154, 1963

6) Stewart, J. M. \& J. D. Young: "Solid phase peptide synthesis" pp. 27 64, W. H. Freeman and Company, San Francisco, Calif., 1969

7) Bergel, F. \& J. A. Stock: Cyto-active amino and peptide derivatives. I. Substituted phenylalanines. J. Chem. Soc. 2409 2417, 1954

8) Honda, I.; Y. Shimonishi \& S. SAKakibara: T-Amyloxycarbonyl as a new protecting group in peptide synthesis. IV. Synthesis and use of $t$-amylazidoformate. Bull. Chem. Soc. Japan 40: 2415 $\sim 2418,1967$

9) Erlanger, B. F.; S. M. Vratsanos, N. Wassermann \& A. G. Cooper: Stereochemical investigation of the active center of pepsin. Biochem. Biophys. Res. Comm. 28: 203 208, 1967

10) Rajagopalan, T. G.; W. S. Stein \& S. Moore: The inactivation of pepsin by diazoacetyl norleucine methyl ester. J. Biol. Chem. 241: 4295 4297, 1966

11) TANG, J.: Specific and irreversible inactivation of pepsin by substrate-like epoxides. J. Biol. Chem. 246: 4510 4517, 1971

12) Hollands, R. \& J.S. Fruton: Kinetics of the hydrolysis of synthetic substrates by pepsin and by acetyl-pepsin. Biochem. 7: 2045 2053, 1968

13) HuAng, W. \& J. TANG: Modification of an arginyl residue in pepsin by 2,3-butanedione. J. Biol. Chem. 247: 2704 2710, 1972

14) Fasella, P.; G.G. Hammes \& P.R. Schimmel: A Sephadex dialysis method of determining small molecule-macromolecule binding constants. Biochim. Biophys. Acta 103: 708 710, 1965

15) Bray, G. A.: A simple efficient liquid scintillator for counting aqueous solutions in a liquid scintillation counter. Anal. Biochem. 1: 279 285, 1960

16) Medzihradszky, K.; I. M. Voynick, H. Medzihradszky-Schweiger \& G. S. Fruton: Effect of secondary enzyme-substrate interactions on the cleavage of synthetic peptides by pepsin. Biochem. 9: $1154 \sim 1162,1970$

17) Morrison, J.F.: Kinetics of the reversible inhibition of enzyme-catalyzed reactions by tightbinding inhibitors. Biochem. Biophys. Acta 185: 269 286, 1969

18) Perlmann, G.E.: Acetylation of pepsin and pepsinogen. J. Biol. Chem. 241: 153 157, 1966

19) SaChdev, G. P.; A. D. Brownstern \& J. S. Fruton: N-Methyl-2-anilinonaphthalene-6-sulfonyl peptides as fluorescent probes for pepsin-substrate interaction. J. Biol. Chem. 248: 6292 6299, 1973 